\title{
The role of A.N. Syzganov and N.F. Kramchaninov in the study of epidemiology, etiology, and prevention of cancer
}

\begin{abstract}
Many issues of cancer epidemiology are not resolved; the incidence remains high. In 1960, Kazakhstani scientists studied the regional features of skin cancer. Many questions and conclusions which modern scientists have come to in the world have been previously studied and resolved in detail by domestic researchers. It is worth to analyze this data, expand its academic circulation, use it in science and practice, and specify the possibilities for resolving cancer prevention issues.
\end{abstract}

Keywords: cancer epidemiology, incidence, etiology, cancer development conditions, prevention.

Introduction: Alexander Nikolayevich Syzganov needs no special introduction, while Nikolay Fedorovich Kramchaninov (1919-1996), a Kazakhstani scientist and healthcare initiator, is hardly known to any of modern doctors. Meanwhile, an analysis of his scientific works (in total about 500 papers, 71 of them are dedicated to oncology), including those compiled in cooperation with A.N. Syzganov, speaks to the fact that he was a great scientist. Their joint work in the 1960s contributed significantly to the oncology development in Kazakhstan. These investigations are not covered in the scientific literature, and it seems that they have to be studied and evaluated yet. In our report, we are going to review only a small, though significant and exciting part of the scientific activity performed by A.N. Syzganov, which N.F. Kramchaninov describes in his works.

A bit of history. Apparently, few people know that the first medical congress in Kazakhstan took place in 1936 in the city of Alma-Ata, and the surgery section was chaired by A.N. Syzganov. Forty-one reports were presented at the section; some of them were devoted to the investigations in the malignancy sphere. The reports prompted a lively debate. A.N. Syzganov noted that the reports and debates on this issue were essential for the healthcare system of Kazakhstan and that the fight against cancer should have been reflected in practical work. He emphasized that the reports had the nature of preliminary communications, and all the points put forward should have been further monitored, clarified, and investigated to a greater extent. $\mathrm{He}$ also drew attention to the need to be careful in identifying conditions that could determine the cancer prevalence. The content of the speech by A.N. Syzganov showed his deep, scientifically sound, and comprehensive view on the problem. Back at that time, he saw the primary solution to this problem in establishing the causes. In this context, we can remind the words of N.I. Pirogov, a well-known surgeon and thinker, «The future belongs to preventive medicine. This science, going hand in hand with medical science, will bring undoubted benefit to humanity» [1].

The study of malignancies was expanding in Kazakhstan in subsequent years. Many doctors and scien- tists made a significant contribution to this work, including not only A.N. Syzganov but also M.I. Bryakin, A.B. Rise, S.B. Balmukhanov, S.N. Nugmanov, T.P. Denyagina, G.F. Shkradyuk, A.B. Fainshmidt, N.I. Kolycheva, L.V. Puterman, I.A. Popova, E.l. Burmistrova, just to name a few. Some of them were employed by the Surgery Institute. The Oncology Institute was not yet established, and the Oncological Department of the Surgery Institute of the Kazakh SSR Academy of Sciences created by A.N. Syzganov dealt with the issues related to cancer.

N.F. Kramchaninov graduated from a medical institute and started working as Deputy Head of the Guryev Region Healthcare Department in 1942. There, he became interested in studying the history of healthcare and epidemiology of infectious diseases that were widespread at that time. He began to study malignant tumors by accident. By 1960, while working in the administrative office of the Kazakh SSR Ministry of Health, he prepared a thesis on the history of healthcare in Western Kazakhstan. Still, the Ministry management did not provide him an opportunity to complete the work. The Surgery Institute, headed by Professor A.N. Syzganov, a member of the Kazakh SSR Academy of Sciences, was at that time looking for a specialist in statistics. Syzganov offered that position to Kramchaninov, appointed him as a junior research fellow, and granted a month to complete the thesis while becoming his dissertation advisor. Then, he instructed Kramchaninov to study the skin cancer prevalence in Kazakhstan and identify its causes. That was the manifestation of the courage and the scope of scientific thinking of Syzganov. According to Kramchaninov, he felt confused and «low spirited» having received such a proposal since he considered that problem to be unsolvable and had no idea where to start and how to act. Only after he got acquainted with the available literature, he found the strength to take up the problem, set to the investigations diligently and presented a report to the Surgical Society of Kazakhstan in October 1960. He collected data of 12 thousand patients (histological data of 2,603 patients) and medical histories of 800 patients following a specially designed program. The studied literature amounted to more than three thousand sources, and 
he was working on his doctoral thesis.

In all his papers, Kramchaninov analyzed skin cancer in terms of regional features and the role of UV in the etiology. A unique, comprehensive epidemiological analysis of incidence made it possible to identify the patterns of prevalence. The incidence in the southern regions was found to be much higher than in the northern ones; it also increased with the elevation of the settlement and the continentality. The incidence among the urban population and women was higher in comparison to villagers and men, who were more exposed to sunlight due to their living conditions. Kramchaninov explained that interesting paradox by the protective properties of the skin (tan, pigmentation) acquired in the conditions of increased insolation. Those conclusions were made based on the studied incidence in people by nationality (to eliminate the influence of customs, habits, clothing features). The incidence in the Kazakh population was 8.5 times lower than in the Russian population (due to skin pigmentation). A study of cancer foci localization showed their prevalence on the face and the open parts of the body as the most exposed to the sunlight (nose, cheeks, etc.). As a result, he concluded that the skin cancer incidence increased commonly due to an increase in the exposure likelihood caused by the expansion of gardening and horticulture (excessive irregular insolation), and the population's neglect of protective methods against excessive exposure. This kind of comprehensive scientific epidemiological analysis involving objective statistical indicators might have taken place for the first time ever. A.N. Syzganov noted the level of detail and made some references to it in his monograph [2].

The author found [3-6] that a carcinogenic effect of UV rays on the cell requires strict conditions: a particular efficacy, directivity, and duration of exposure. The most dangerous period is June till August, especially at noon, when the rays continuously affect the skin at the right angle for 20-30 minutes. Skin cancer can only develop due to the irradiation of a dividing cell in the prophase stage. Irradiation dehydrates chromosomal protein. It turns into an insoluble substance causing «eternal» cell division.

Kramchaninov proposed a concept of «cancer days» (3-5 during the summer), meaning the days with the most favorable conditions for cancer development [3-6]. He revealed the unevenness of incidence by month and associated it with medical histories to determine the latent period (from the occurrence of the disease until the onset of clinical manifestations). It appeared that skin cancer occurred on average 4.2 months after exposure, with the period ranging from 57 days 11 months. The author explained such a variety by the difference in the number of cells simultaneously subjected to malignization (conversion into cancer cells).

Kramchaninov tried to cause skin cancer in himself or animals, but he failed since all exposures occurred on «non-cancerous» days due to high humidity and low irradiation.

The proposed hypothesis of skin cancer etiology and pathogenesis was confirmed by the study of medical histories of patients (all of them were exposed to prolonged and excessive irradiation). That hypothesis has scientifical- ly justified the established patterns in incidence and became the basis for the proposed specific preventive measures based on preventing the adverse UV rays' impact. The specific nature of that skin cancer carcinogenesis hypothesis made possible an experimental clarification of the mechanism of action of putative carcinogenic factors on the cell and to verify in practice the effectiveness of the resulting preventive measures. Thus, the studies supervised by Syzganov addressed the most critical problems of oncology, which were to be solved to ensure effective prevention. Time and practice will show how successful it has been done.

A.N. Syzganov had quite a wide range of scientific interests in general and in the field of oncology, in particular. He studied esophagus cancer, the statistics of incidence and mortality, regional epidemiological features, etiology, and pathogenesis. He actively helped his students and employees in scientific and practical work. For instance, he advised Kramchaninov to study the possible causes of lung cancer, thus initiating the statistical studies of carefully collected medical histories of 250 patients with lung cancer. It was found that $46.8 \%$ of cancer patients previously had pulmonary diseases, which could have form the basis for cancer development [7]. Kramchaninov was also unsure about the carcinogenic effect of tobacco.

The statistical study of medical histories of cancer patients allowed to determine the specific industrial enterprises, workshops, as well as areas of agriculture and some other activities with the conditions favorable for lung cancer development. Along with that, the study determined the nature of preventive anti-cancer measures in the production environment. He noted a general nature of the majority of preventive measures taken.

The author noted that the established country-wide and regional-specific intensive indicators lacked differentiation, and they could demonstrate only the general lung cancer incidence. The highest of them should be viewed as signaling of some existing (often yet unknown) conditions that contributed to increased incidence. Of course, that required to organize the identification of causes. According to the author, the statistical study of factors contributing to cancer development should be combined with the study of the features of the production environment at industrial enterprises and in agriculture or the living conditions.

The Oncology Department of the Surgery Institute of the Kazakh SSR Academy of Sciences conducted important studies of the reasons for cancer neglect. The results were reported by Kramchaninov on March 15, 1962, at the Kazakhstan Society of Surgeons [8]. The study of 915 relevant protocols showed the following (Table 1):

A joint article by Syzganov and Kramchaninov, «Regional features of incidence and prevalence of malignant neoplasms in the Kazakh SSR» [9], is of great scientific and practical value. Let us bring its content to a sharper focus. In the beginning of the article, the authors noted that, despite the great efforts of health authorities, the percentage of inoperable malignant neoplasms remained high. In those conditions, correct scientifically-ground registration of malignant neoplasm incidence was vital since it formed the basis for arranging efficient and sufficient pre- 
ventive and curative actions. The authors determined the intensive cancer incidence rates in Kazakhstan and the regions, as more reliable ones. Such processing of statistical materials took place in Kazakhstan for the first time. It is worth mentioning that even the scientific literature available back then provided only proportionate incidence rates (that is, the share of patients among the population), which was methodologically wrong. Therefore, the materials of that article could serve as a starting point for the formation of scientific epidemiology of malignant diseases, and not only in Kazakhstan, and the authors could literally be considered its founders.

Table 1 - The results of the study of reasons for cancer neglect [8]

\begin{tabular}{|c|c|c|c|}
\hline No. & Reasons & Total cases & $\%$ of the total \\
\hline 1. & Incomplete patient examination & 82 & 8.9 \\
\hline 2. & $\begin{array}{l}\text { Diagnostic errors: } \\
\text { clinical } \\
\text { radiological } \\
\text { histopathological }\end{array}$ & $\begin{array}{c}125 \\
32 \\
- \\
\end{array}$ & $\begin{array}{c}13.7 \\
3.5 \\
- \\
\end{array}$ \\
\hline 3. & Long patient examination & 60 & 6.6 \\
\hline 4. & Asymptomatic disease course & 261 & 28.5 \\
\hline 5. & Late appeal for medical help & 355 & 38.8 \\
\hline
\end{tabular}

It would be interesting to compare these results with the current data.

The article presented incidence data (per 100,000 thousand) by clinical types of cancer over time from 1951 to 1959 for all regions of Kazakhstan. Among those detected, the most common were stomach, uterus, skin, esophagus, and lung cancers. Rectum and larynx cancers showed the lowest incidence. The incidence of almost all cancer types was growing year by year, especially that referred to esophagus cancer (1.5 times growth) and lung cancer (3 times growth). The authors emphasized that the number of cancer patients was growing all over the world; therefore, the detected increase in incidence rates in Kazakhstan should have attracted serious attention. Some specific features of cancer incidence were established in certain areas. Relatively high lung cancer incidence was registered in Almaty, Semipalatinsk, and North Kazakhstan regions. Given the significant increase in this type of cancer in Kazakhstan over the last years, the authors noted the need to study this phenomenon thoroughly, as well as to explain the uneven incidence rates of other types of cancer. Cancer incidence was generally higher among urban residents than among rural populations. At the same time, the incidence of esophagus cancer was higher in rural areas, while lung and skin cancers prevailed in urban areas. The authors noted the need for special studies to explain the difference in incidence rates of specific cancers. The incidence in men and women was almost similar, except for lip, lung, esophagus, and stomach cancers, which affected men hugely more often. A study of incidence rates for 1959 showed a gradual increase in incidence with age in men and women. However, in the population above 70 years, the incidence of cancer of different localizations was decreasing, except for skin cancer. It was significant that the authors had critically evaluated the obtained statistics, called it approximate due to the incomplete registration of patients, and comprehensively analyzed the reasons that complicated the correct scientific characterization of incidence. A.N. Syzganov reviewed the obtained results critically, which was peculiar for his scientific thinking.

The authors examined clinical issues in considerable detail and were focused on improving the quality of work. Cancer detection at early stages was at a low level, signif- icant shortcomings in diagnostics of cancer of specific localizations were due to insufficient qualification of medical workers, and the lack of specialized equipment. Not all patients of the second clinical group received the necessary treatment, due to which the disease was apparently turning into a neglected form, in particular, in the case of esophagus and lung cancers. In 1959, an astonishing number of patients applied to medical institutions throughout the republic with advanced forms of cancer $-30.6 \%$ of all the registered cancer cases. $55.4 \%$ of patients with esophagus cancer, $49.1 \%$ with stomach cancer, $44.7 \%$ with rectum cancer, and $49.2 \%$ with lung cancer had stage IV clinical group at diagnosis.

The authors considered the mortality rates to be important for the assessment of the quality of anti-cancer activities. They noted an increase in the share of fatal cases each year (from $2.5 \%$ in 1940 to $16.3 \%$ in 1958), which could be associated not only with an increase of incidence worldwide but also with the gaps in preventive care for the population. Cancer mortality per 100 thousand increased from 79.18 in 1957 to 86.96 in 1959. High mortality was associated with stomach, esophagus, and lung cancers; the mortality from uterus cancer was relatively high. Those rates once again emphasized the insufficient arrangement of medical and preventive care.

The authors analyzed some modern preventive methods available at that time: identifying and treating precancerous diseases during systematical preventive examinations, scientific processing of statistical incidence data, establishing patterns of cancer development and determining carcinogenic environmental factors, and noted the relevance of using epidemiological principles in the fight against cancer. "An oncologist, like an epidemiologist, shall study not only the incidence among various population groups but also take into account the factors that affect the development of certain types of cancer» [7]. These words written 58 years ago still sound relevant today.

Then, the authors analyzed the role of various carcinogenic factors and hygienic conditions, smoking, etc. As regards the physical factors of cancer occurrence, they noted the role of high temperature, in particular, excessively hot food, in esophagus cancer genesis, and the role of bad habits, such as scratching, tearing of warts and birth- 
marks, in the skin cancer genesis. N.F. Kramchaninov has developed that approach in his subsequent studies and explained many incidence points from the perspective of living conditions and behavioral features. The authors critically evaluated the viral theory of cancer, paying attention to the role of the internal physiological environment of the body in cancer genesis, namely, the susceptibility to carcinogenic effects, the significance of allergic reactivity, the role of gender, age, etc. The variety of factors contributing to cancer development signalized the importance of their identification in domestic and industrial conditions for the development and implementation of effective anti-cancer measures.

Conclusion: Thus, the studies conducted or initiated by A.N. Syzganov were notable for their practical orientation, materialistic understanding of the relationship between the disease development processes and the social conditions of living, the behavior, and habits. Scientists have long been discussing the role of environmental factors and genetic predisposition in malignant tumor etiology. Until recently, the environmental factors and genetic predisposition were thought to dominate. However, the assessment of primary cell mutations has shown that 70 to $90 \%$ of them are directly related to the influence of harmful environmental impact and behavior [10]. Such conclusions allow looking realistically and with great optimism at the capacity of prevention activities and active participation of healthy people and patients in health maintenance. This data clearly demonstrates that A.N. Syzganov, his students, and employees have chosen the right direction and made a worthy contribution to the development of science and practice of combating malignant tumors.

\section{References:}

1. Pirogov N.I. Nachala obshchey i voyenno-polevoy khirurgii Basics of general and field surgery]. Cit. by: Gigiyena s osnovami ekologii cheloveka. Uchebnik [Hygiene with the basics of human ecology. Textbook] / ed. Prof. P.I. Melnichenko.- Moscow: Geotar Media, 2011. - 752 p. [in Russian];

2. Syzganov A.N. O nekotorykh usloviyakh razvitiya zlokachestvennykh opukholey [About some conditions of development of malignant tumors]. - Alma-Ata: Science, 1970. - 243 p. [in Russian];

3. Kramchaninov N.F. Krayevyye osobennosti rasprostraneniya raka kozhi v Kazakhstane [Regional features of skin cancer preva- lence in Kazakhstan] // Yearbook of scientific works: Proceedings of Alma-Ata Institute of Postgraduate Medical Education of the USSR Ministry of Health. - Alma-Ata, 1967. Vol. 3. - P. 474-478 [in Russian];

4. Kramchaninov N.F. Materialy $k$ istorii izucheniya zlokachestvennykh opukholey $v$ Kazakhstane [Materials on the history of malignant tumor study in Kazakhstan] // Proceedings of Alma-Ata Medical Institute. - Alma-Ata, 1969. - Vol. 25. - P. 364-368 [in Russian];

5. Kramchaninov N.F. Materialy $k$ izucheniyu zabolevayemosti naseleniya Kazakhstana rakom kozhi [Materials to the study of skin cancer incidence among Kazakhstan population] // Voprosy klinicheskoy i eksperimental'noy onkologii: Trudy Instituta klinicheskoy i eksperimental'noy khirurgii Akademii nauk Kazakhskoy SSR. [Issues of clinical and experimental oncology: Proceedings of the Institute of Clinical and Experimental Surgery of the Kazakh SSR Academy of Sciences]. - Alma-Ata, 1962. - Vol. 8. - P. 73-79 [in Russian];

6. Kramchaninov N.F. Materialy k istorii izucheniya raka kozhi $v$ Kazakhstane [Materials to the history of skin cancer study in Kazakhstan] // Materials of the 10th scientific and practical conference of KIEM. Part I. Issues of virology and viral infections. Healthcare Organization and the History of Medicine. - Alma-Ata, 1969. - P. 193196 [in Russian];

7. Babashev B.S., Kramchaninov N.F. Materialy k kharakteristike raka legkogo $v$ Kazakhstane. Voprosy onkologii i radiologii [Materials for lung cancer characterization in Kazakhstan. Problems of oncology and radiology] // Abstracts of the VI conference of oncologists and radiologists of the Kazakh SSR, together with a visiting session of the Oncology Institute of the USSR Medical Science Academy. - Alma-Ata, 1962. - P. 28 [in Russian];

8. Kramchaninov N.F., Zakharova A.B. Materialy k izucheniyu prichin zapushchennosti raka (po protokolam na vyyavleniye zapushchennoy formy zlokachestvennoy opukholi) [Materials for the study of causes of cancer neglect (according to the protocols of advanced malignant neoplasm detection)] // Materials of the 7th scientific and practical conference of the institute and the conference of doctors of Northern Kazakhstan: proceedings of the Kazakh Institute of Epidemiology, Microbiology and Hygiene. - Alma-Ata, 1966. - P. 242-244 [in Russian];

9. Syzganov A.N., Kramchaninov N.F. Krayevyye osobennosti zabolevayemosti i rasprostraneniya zlokachestvennykh novoobrazovaniy $v$ Kazakhskoy SSR [Regional features of incidence and prevalence of malignant neoplasms in the Kazakh SSR] // Voprosy klinicheskoy i eksperimental'noy onkologii: Trudy Instituta klinicheskoy i eksperimental'noy khirurgii Akademii nauk Kazakhskoy SSR [Issues of clinical and experimental oncology: Proceedings of the Institute of Clinical and Experimental Surgery of the Kazakh SSR Academy of Sciences]. - Alma-Ata, 1962. - Vol. 8. - P. 3-11 [in Russian];

10. Wu S., Powers S., Zhu W., Hannun Y.A. Substantial contribution of extrinsic risk factors to cancer development // Nature. 2016. - Vol. 529. - P. 43-47. 